\title{
The Effect of Irrigation Treatment on the Growth of Lavender Species in an Extensive Green Roof System
}

\author{
Angeliki T. Paraskevopoulou ${ }^{1, *}$, Panagiotis Tsarouchas ${ }^{1}$, Paraskevi A. Londra ${ }^{2}$ and \\ Athanasios P. Kamoutsis ${ }^{3}$ (D) \\ 1 Laboratory of Floriculture and Landscape Architecture, Department of Crop Science, School of Plant \\ Sciences, Agricultural University of Athens, Iera Odos 75, 11855 Athens, Greece; pan.tsarouchas@gmail.com \\ 2 Laboratory of Agricultural Hydraulics, Department of Natural Resources Management and Agricultural \\ Engineering, School of Environment and Agricultural Engineering, Agricultural University of Athens, \\ Iera Odos 75, 11855 Athens, Greece; v.londra@aua.gr \\ 3 Laboratory of General and Agricultural Meteorology, Department of Crop Science, School of Plant Sciences, \\ Agricultural University of Athens, Iera Odos 75, 11855 Athens, Greece; akamoutsis@aua.gr \\ * Correspondence: aparas@aua.gr; Tel.: +30-210-529-4551
}

Received: 30 January 2020; Accepted: 17 March 2020; Published: 19 March 2020

\begin{abstract}
In green roofs, the use of plant species that withstand dry arid environmental conditions and have reduced water requirements is recommended. The current study presents the effect of irrigation amount on the growth of four different species of lavender; Lavandula angustifolia, Lavandula dentata var. candicans, Lavandula dentata var. dentata, and Lavandula stoechas established on an extensive green roof system and used in urban agriculture. Two irrigation treatments (high and low) determined by the substrate hydraulic properties were applied. Plant growth studied at regular intervals included measurements of plant height, shoot canopy diameter, plant growth index, shoot dry weight and stomatal conductance. The results were consistent and showed that low irrigation reduced plant growth. With the exception of L. stoechas, the appearance of plants watered with the low irrigation treatment was satisfactory, and their use under low water amount irrigation is supported. Interspecies differences among lavender species were present in both irrigation treatments. Overall, L. dentata var. candicans showed the greatest growth, followed in descending order by L. dentata var. dentata and L. angustifolia. In parallel, for stomatal conductance, L. dentata var. candicans showed the lowest value, similar to L. dentata var. dentata, and L. angustifolia the largest. Differences in plant characteristics and size among the latter three species can be considered in the design of extensive green roof systems. The use of substrate hydraulic properties was shown to be important for irrigation management on extensive green roof systems.
\end{abstract}

Keywords: drought tolerance; substrate hydraulic properties; substrate available water; ornamental; aromatic; urban agriculture; green infrastructures

\section{Introduction}

There is increasing interest in urban agriculture due to the related economic, social and environmental functions contributing to the sustainability of cities [1]. Though urban agriculture usually highlights food production, it includes the cultivation of other plants such as ornamentals [2], as well as agricultural systems that relate to recreation and leisure [3]. However, within cities, land and soil are limited resources [4]. Generally, cities are characterised by dense buildings, green spaces which are limited in number and size and large impervious paved areas. These characteristics have contributed to creating adverse environmental conditions within the cities such as the heat island effect, restricted air flows, human discomfort and poor health caused by heat stress and poor air 
quality [5]. Roof greening (the development of planting on buildings, i.e., green roofs) is one means by which urban agriculture may be realized $[1,6]$; it has the potential to contribute to mitigating the problems caused by urbanisation on an individual scale, and when applied broadly, could improve the environment of a city [5].

Green roofs are generally classified into three categories depending on weight, substrate layer, maintenance, cost, plant community, and irrigation, i.e., extensive, semi-intensive and intensive roofs [7]. Within cities, the load-bearing capacity of many buildings, particularly older ones, is limited; hence, only extensive green roof systems can be applied on these buildings due to their smaller weight load in comparison to other green roof systems. Extensive green roofs are characterised by shallow depths and reduced water availability. Water is an additional limited natural resource within many cities, particularly in semiarid and arid locations such as the Mediterranean, and especially during the summer months [8]. Furthermore, in Mediterranean regions, high temperatures make the development of green roofs more difficult [9]. Under the increasing threat of climate change, water conservation is a priority. Therefore, it is critical in extensive green roofs to use plant species that withstand dry heat and water-deficits [10]. In recent years, research on the growth of shrubs in extensive green roofs is increasing [8,11-16]. Plant growth in extensive green roofs with limited irrigation was found to be satisfactory for Artemisia absinthium L., Helichrysum italicum Roth., Helichrysum orientale L. [11,12], Origanum majorana L., and Santolina chamaecyparissus L. [12] at a substrate depth of $7.5 \mathrm{~cm}$, and for Arthrocnemum macrostachyum, Halimione portulacoides [8], Convolvulus cneorum L. [13,14], Origanum dictamnus L. [14], Atriplex halimus [16], and Pallenis maritima [15] at a substrate depth of $10 \mathrm{~cm}$.

Generally, the literature on drought-resistant plants for use in agriculture and landscape architecture is extensive [17]. On the other hand, there is a need to study the survival of shrubs on green roofs in hot and dry climates [10]. The amount of water loss in extensive green roofs is a function of three properties of the green roof system, i.e., plant water uptake and transpiration, shading of substrate by vegetation that might reduce the substrate surface evaporation rate and greater water holding capacity of the substrates containing plant roots [18]. A balance among species of water and substrate is needed to address the adverse environmental conditions of green roofs and the effect of temperature extremes [19]. Therefore, plant selection and the improvement of the available amount of water to plants are key research aims [9]. Plant survival on green roofs with shallow substrates and low water availability is not easily understood, and is determined by a combination of drought avoidance physiological processes [10] such as the decline of stomatal conductance, and hydraulic conductivity [20] expressed by species in various ways that include dormancy, drought deciduousness and stomatal regulation [10]. Several authors believe that the first response of plants to severe drought is the closure of their stomata to prevent transpiration water loss [21-23]. Species that are well adapted to drought, such as Olea europaea L., decrease water loss through stomatal closure from early in the morning [24]. Stomatal conductance plays an essential role in regulating plant water balance and may reduce plant transpiration [23]; however, it may also concomitantly reduce cell expansion and growth rate, leading to reduced biomass and yield [22,25].

In accordance with De Boodt and Verdonck [26], plant growth decreases when water retention in substrates occurs at negative pressure heads greater than $-100 \mathrm{~cm}$, and inadequate substrate aeration conditions for plant growth are created when negative pressure heads are less than $-10 \mathrm{~cm}$. Therefore, retaining substrate water content within the available water range defined by negative pressure heads between -10 and $-100 \mathrm{~cm}$ during irrigation ensures substrate water availability and plant water uptake, thereby reducing the effect of water stress. A comparative study for investigating plant growth among different lavender species (family: Lamiaceae) on a simulated extensive green system and under different irrigation treatments determined by the hydraulic properties of the substrate has not been undertaken before. Lamiaceae is characterised by numerous aromatic species of arid and warm climates. The Lavandula genus includes 47 species and many varieties [27]. The qualitative characteristics of the different species such as the habit and morphological characteristics of the flowers and foliage vary $[28,29]$, and are of interest to both landscape and urban agriculture. In this study, 
the hydraulic properties of an extensive green roof system substrate were used to determine different amounts of irrigation within the available water range defined by negative pressure heads between -10 and $-100 \mathrm{~cm}$. The objective of this study was to investigate the effect of irrigation amount on the growth of 4 lavender species, i.e., Lavandula angustifolia, Lavandula dentata var. candicans, Lavandula dentata var. dentata and Lavandula stoechas on an extensive green roof system under two irrigation treatments (high and low) in the aforementioned available water range to support the creation of aesthetically-pleasing green roofs for urban agriculture.

\section{Materials and Methods}

\subsection{Experimental Setup}

Four popular lavender species were selected for study, Lavandula angustifolia, Lavandula dentata var. dentata, Lavandula dentata var. candicans and Lavandula stoechas. Uniform, $9 \mathrm{~cm}$ size pot lavender plants were supplied by the Kalantzis Plants (Marathonas, Greece) nursery. Plants were individually transplanted on 1 March 2016 in rectangular shaped $60 \mathrm{~cm} \times 40 \mathrm{~cm}$ plastic containers $(1$ plant per container), simulating an extensive green roof system comprised bottom-up from a water retention and protection layer, a drainage layer, a filter layer, and $10 \mathrm{~cm}$ deep substrate [8]. The substrate used was $S_{15}:$ Pum $_{70}: C_{15}$ and consisted of soil (S), pumice (Pum) and grape marc compost (C) in a volumetric ratio of 15:70:15. Containers were positioned on metal benches ( $0.80 \mathrm{~m}$ height) on the roof of the main building of the Agricultural University of Athens (lat. $37^{\circ} 58^{\prime} 57^{\prime \prime} \mathrm{N}$, long. $23^{\circ} 42^{\prime} 17^{\prime \prime} \mathrm{E}$, alt. $30 \mathrm{~m}$ ) to avoid the effect of shading from the perimeter walls of the roof. After transplanting, plants were left to grow and establish for 3 months (1 March-30 May 2016). An automated irrigation system was applied using a drip system with two emitters of $2 \mathrm{~L} \mathrm{~h}^{-1}$ per plant spaced at $10 \mathrm{~cm}$ on either side of the plant and a total irrigation water application rate of approximately $16.6 \mathrm{~mm} \mathrm{~h}^{-1}$. Throughout the study period on a monthly basis, $1.2 \mathrm{~g} \mathrm{~L}^{-1} \mathrm{H}_{2} 0$ Nutri-Leaf 20-20-20 (Miller Chemical and Fertilizer Corporation, U.S.A.) of fertilizer was applied to all plants. During the experiment, there was no leaching from the applied fertilizer, as the water application rate was gradual and the applied irrigation amount produced no water excess (see 2.3. Experimental Design and Irrigation Treatments). The duration of the experiment was 4 months and took place mainly over the summer months, from 31 May (day 1) to 30 September 2016 (day 123).

\subsection{Physical-Hydraulic Properties of Substrate}

The $S_{15}:$ Pum $_{70}: C_{15}$ substrate had a bulk density $\rho_{\varphi}=1.035 \mathrm{~g} \mathrm{~cm}^{-3}, \mathrm{pH}=7.8$ and $\mathrm{EC}=1.33 \mathrm{dS} \mathrm{m} \mathrm{m}^{-1}$ (the latter two measurements were made in 1:1 solution extract). The soil used was sandy loam/loam (53.62\% sand, $30.82 \%$ silt, $15.56 \%$ clay, $0.7 \%$ organic matter), the pumice contained particles of diameter size 0.06-8 mm (LAVA, Mining \& Quarrying A.D, Athens, Greece) and the grape marc compost (i.e., a waste product of wine production) was composted for 20 months and used as a sustainable alternative to peat. The particle size distribution of the substrates was determined with screen analysis. Weighed substrate samples were placed in the top sieve of a column of sieves arranged from top to bottom in descending order of screen mesh size $(>20.00,16.00,10.00,8.00,4.00,2.00,1.00,0.50,0.25,0.106$, and $<0.053 \mathrm{~mm}$ ) resting on a sieve shaker for $3 \mathrm{~min}$ at 30 shakes per minute.

A tension plate apparatus in a Haines-type assembly [30], with an air-entry value of $-180 \mathrm{~cm}$ of a water column was employed to define the substrate water retention curve. The substrate sample of $3 \mathrm{~cm}$ in height and $10.2 \mathrm{~cm}$ in diameter was positioned on the vibrating porous plate of a Buchner filter funnel to achieve satisfactory packing. It was then subjected to gradual wetting from the bottom of the plate until saturation (for $48 \mathrm{~h}$ ). Measurements of the water content at different pressure heads were taken to obtain the water retention curve. The retention curve was the mean of three substrate samples $(n=3)$. 
The RETC program [31] was used to calculate the fitting hydraulic parameters of the widely used Mualem-van Genuchten model [32,33] on the experimental water retention data. Van Genuchten [33] described the water retention curve as

$$
\theta(H)=\left(\theta_{s}-\theta_{r}\right)\left(\frac{1}{1+(\alpha|H|)^{n}}\right)^{m}+\theta_{r}
$$

where $\theta$ denotes the soil water content $\left(\mathrm{cm}^{3} \mathrm{~cm}^{-3}\right)$, subscripts $\mathrm{s}$ and $\mathrm{r}$ denote the saturated and residual values of water content, $\alpha$ is the curve-fitting parameter inversely proportional to the mean pore diameter $\left(\mathrm{cm}^{-1}\right)$, and both $m, n$ are dimensionless shape curve-fitting parameters, $m=1-1 / n$ and $0<m<1$.

Combining Equation (1) with the model developed by Mualem [32], the relationship between hydraulic conductivity and soil water content, $K(\theta)$, can be calculated as

$$
K(\theta)=K_{s}\left(\frac{\theta-\theta_{r}}{\theta_{s}-\theta_{r}}\right)^{0.5}\left\{1-\left[1-\left(\frac{\theta-\theta_{r}}{\theta_{s}-\theta_{r}}\right)^{1 / m}\right]^{m}\right\}^{2},
$$

The model fitting parameters described above were evaluated by the RETC program using the measured water retention and saturated hydraulic conductivity data. The unknown parameters of the Mualem-van Genuchten model in the parameter optimization process to fit the water retention function were $\alpha, n$ and $\theta_{r}$.

The saturated hydraulic conductivity, $K_{s}$, was determined by the constant-head method [34].

\subsection{Experimental Design and Irrigation Treatments}

The effect of the amount of irrigation water on the plant growth of the four selected lavender species (Lavandula angustifolia, Lavandula dentata var. dentata, Lavandula dentata var. candicans and Lavandula stoechas) was studied. The plant containers were arranged in a randomised design with 6 replicates per species. The amount of irrigation water was based on the substrate available water defined by the water retention curve of the substrate (i.e., water content released between -10 and $-100 \mathrm{~cm}$ pressure head). Two irrigation treatments, i.e., high and low amounts of water, were applied through the automated irrigation system using two irrigation 9001 controllers (Galgon, Kfar Blum, Israel). Plants irrigated with a high amount of water were not subjected to water stress and served as the control. The above irrigation treatments were applied for 4 months from day 1 of the experiment (31 May 2016) until day 123 (30 September 2016). Substrate water content was measured daily using a handheld Frequency Domain Reflectometry (FDR) soil moisture sensor (HH2, Delta-T Devise, Cambridge, U.K.; WET Sensor type WET-2, Delta-T Devise, Cambridge, U.K.) set at the 'mineral' setting and calibrated to the used substrate. The sensor was fully inserted into the substrate with the central rod positioned $5 \mathrm{~cm}$ away from the plant centre. During the high irrigation treatment, when the FDR sensor showed a water content value of approximately $0.31 \mathrm{~cm}^{3} \mathrm{~cm}^{-3}$ (at corresponding pressure head $-50 \mathrm{~cm}$ ), the plants were irrigated with $1.95 \mathrm{~L}$, ensuring water availability within the easily available water (EAW) area. In the case of the low irrigation treatment, plants were irrigated with half the amount of the high irrigation treatment, i.e., $0.975 \mathrm{~L}$, when the FDR sensor showed a water content value of approximately $0.29 \mathrm{~cm}^{3} \mathrm{~cm}^{-3}$ (at corresponding pressure head $-100 \mathrm{~cm}$ ).

\subsection{Plant Growth Biometrics}

On day 1, plant size (height and shoot canopy diameter) was similar among species. Plant height (determined from the pot rim of the substrate surface), shoot canopy diameter (average of the widest and perpendicular to the widest plant diameter), and growth index [(height + widest width + perpendicular width)/3] were measured at monthly intervals. In all plants, at the end of the experiment (30 September/ day 123), stomatal conductance was recorded on the abaxial surface of the third or 
fourth fully expanded leaf from the stem base on the exterior of the plant using the AP4 Porometer (Delta-T Devices, Cambridge UK). Measurements were taken between 13:00-14:00 $\mathrm{h}$ and three readings were recorded per plant and averaged. Next, in all plants, shoots were individually harvested at the end of the experiment (day 123). In all species and both irrigation treatments, plant roots penetrated the substrate and could not be separated from the substrate without partial loss of the fine root system; therefore, it was decided that the plant roots would not be harvested. The harvested shoots were dried in an oven at $70^{\circ} \mathrm{C}$ for $48 \mathrm{~h}$, and their dry weights were determined. Finally, in all plants, the percentage increase in plant height, shoot canopy diameter and growth index (GI) was calculated by dividing the difference between the last and first corresponding measurement with the first corresponding measurement and then multiplying by a hundred. Weekly recordings of observations for potential signs of water stress were undertaken throughout the duration of the experiment. In plants, the onset of visual symptoms induced by drought (leaf and stem chlorosis and necrosis) was recorded during the experiment and assessed at the end (on day 123). Visual symptoms induced by irrigation treatments were assessed on a 6-point scale from 0-5, where 0: plant mortality, 1: very severe leaf rolling and chlorosis $>75 \%$, 2: severe leaf rolling and chlorosis 50-75\% approximately, 3: moderate leaf rolling and chlorosis $25-50 \%$ approximately, 4: mild leaf rolling and chlorosis $<25 \%$, 5: no leaf injury.

\subsection{Meteorological Conditions}

Meteorological data were obtained by the nearby meteorological station at Thissio (lat. $38^{\circ} 0.00^{\prime}$ $\mathrm{N}$ long. $23^{\circ} 43.48^{\prime} \mathrm{E}$, alt. $110 \mathrm{~m}$ ) of the National Observatory of Athens, located $1.8 \mathrm{~km}$ away from the experimental site [35]. In 2016, the average daily temperatures ranged between $19.9^{\circ} \mathrm{C}$ on 25 September, and $32.8^{\circ} \mathrm{C}$ on 21 June, while the absolute maximum and minimum air temperature values of $39.9^{\circ} \mathrm{C}$ and of $16.5^{\circ} \mathrm{C}$ were recorded on 21 June and 26 September, respectively (Figure 1). Diurnal temperature range $\left(\mathrm{T}_{\max }-\mathrm{T}_{\min }\right)$ fluctuated between $4.4-14.1^{\circ} \mathrm{C}$ with an average of $8.8^{\circ} \mathrm{C}$. In more detail, during the initial period of the experiment, i.e., 31 May (day 1) until 30 June (day 31), warm thermal conditions dominated, ranging from $17.3^{\circ} \mathrm{C}$ to $39.8^{\circ} \mathrm{C}$. In August, air temperature continued to fluctuate from $21.8^{\circ} \mathrm{C}$ to $38.5^{\circ} \mathrm{C}$. A decrease in air temperature was observed during the end of the experimental period-from 1 September (day 94) to 30 September (day 123)—with fluctuations from $16.5^{\circ} \mathrm{C}$ to $32.9^{\circ} \mathrm{C}$. Overall, July (day 32-62) and August (day 63-93) were the hottest months during the experiment.

Throughout the experiment period, there was very little precipitation concentrated near the start (4 days in June) and end (6 days in September) (Figure 1). More specifically, on 7 and 28 June, 2016 precipitation was approximately 7.6 and $9.6 \mathrm{~mm}$, respectively, and on all the other rainy days, the precipitation was $<2 \mathrm{~mm}$. Furthermore, there was no rainfall in either July or August 2016. During the experiment, both July and August showed the least relative humidity (Figure 1). Hence, the hottest and least humid period of the experiment took place during days 33-93 (1 July and 31 August 2016). Furthermore, the air temperature values were higher, while the precipitation and relative humidity values were less than the corresponding climatic (normal) values (reference period 1961-1990). Therefore, during the time of the experiment, more hot and dry conditions than the climatic values prevailed [35]. Furthermore, measurements of meteorological stations are typically representative within a $10 \mathrm{~km}$ radius [36]. In the current study, the experimental site was located 1.8 away from the meteorological station; therefore, the obtained meteorological data are representative. Microclimate conditions of the experimental site were not recorded, however, due to the adverse environmental conditions of the extensive green roofs [22], and it is likely that the ambient temperate and relative humidity levels were greater and less than the corresponding data obtained from the meteorological station. 


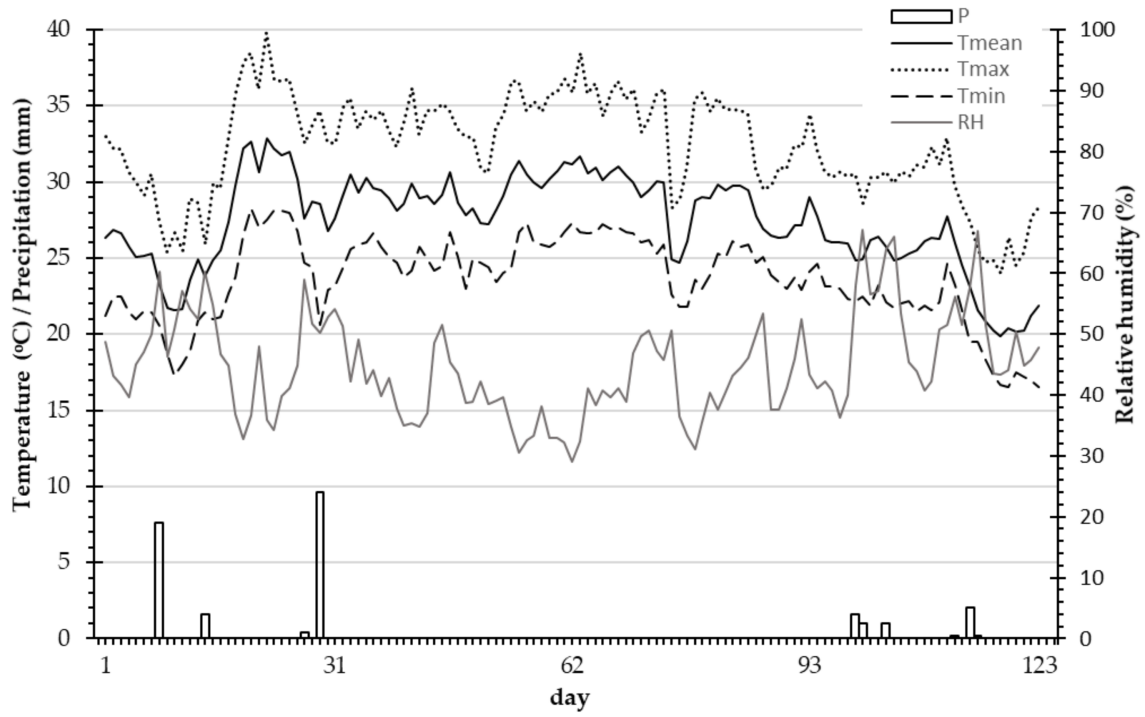

Figure 1. Diurnal mean, maximum and minimum air temperatures, precipitation and relative humidity during the simulated extensive green roof experiment on the main building of the Agricultural University of Athens from 31 May (day 1) to 30 September (day 123) in 2016. P: precipitation (mm); $\mathrm{T}_{\text {mean }}, \mathrm{T}_{\max }$ and $\mathrm{T}_{\min }$ : mean, maximum and minimum temperature $\left({ }^{\circ} \mathrm{C}\right)$, respectively; $\mathrm{RH}$ : relative humidity (\%) [35].

\subsection{Experimental Design and Statistical Analysis}

The experiment followed a completely randomized design with four lavender species and two irrigation treatments, with six replicates per species and irrigation treatment combination. A two-way analysis of variance of the experimental data was performed using SPSS Statistical Software v. 17.0 (SPSS Inc., Chicago, U.S.A.) and treatment means were compared using Tukey HSD test at a probability level $p<0.05$.

\section{Results and Discussion}

\subsection{Physical-Hydraulic Properties of Substrate}

Particle size distribution affects the aeration and water retention properties of substrates [37,38]. The particle size distribution of the substrate used is presented in Table 1.

Table 1. Particle size distribution of $S_{15}: P m_{70}: C_{15}$ substrate (subscripts show volumetric proportions of S:soil, Pum: pumice and C: grape marc compost).

\begin{tabular}{cc}
\hline Particle Size $(\mathbf{m m})$ & Particle Size Distribution $(\% \mathbf{b y} \mathbf{w t})$ \\
\hline$>10$ & 0.00 \\
$10-8$ & 0.34 \\
$8-4$ & 13.55 \\
$4-2$ & 23.16 \\
$2-1$ & 12.49 \\
$1-0.5$ & 8.98 \\
$0.5-0.25$ & 12.25 \\
$0.25-0.106$ & 23.34 \\
$0.106-0.053$ & 4.54 \\
$<0.053$ & 1.35 \\
\hline
\end{tabular}

Knowledge of both basic hydraulic properties of substrates, $\theta(\mathrm{H})$ and $K(\theta)$ is essential for irrigation management [39-41]. The measured and predicted water retention data of the substrate used are 
presented in Figure 2. As shown, there was a very good agreement between the experimental and predicted values of the water retention curve, indicating that the Mualem-van Genuchten model fitting parameters $\alpha, n$ and $\theta_{r}$ provide an adequate description of $\theta(\mathrm{H})$ with a high value of the coefficient of determination $R^{2}$ (0.9977).

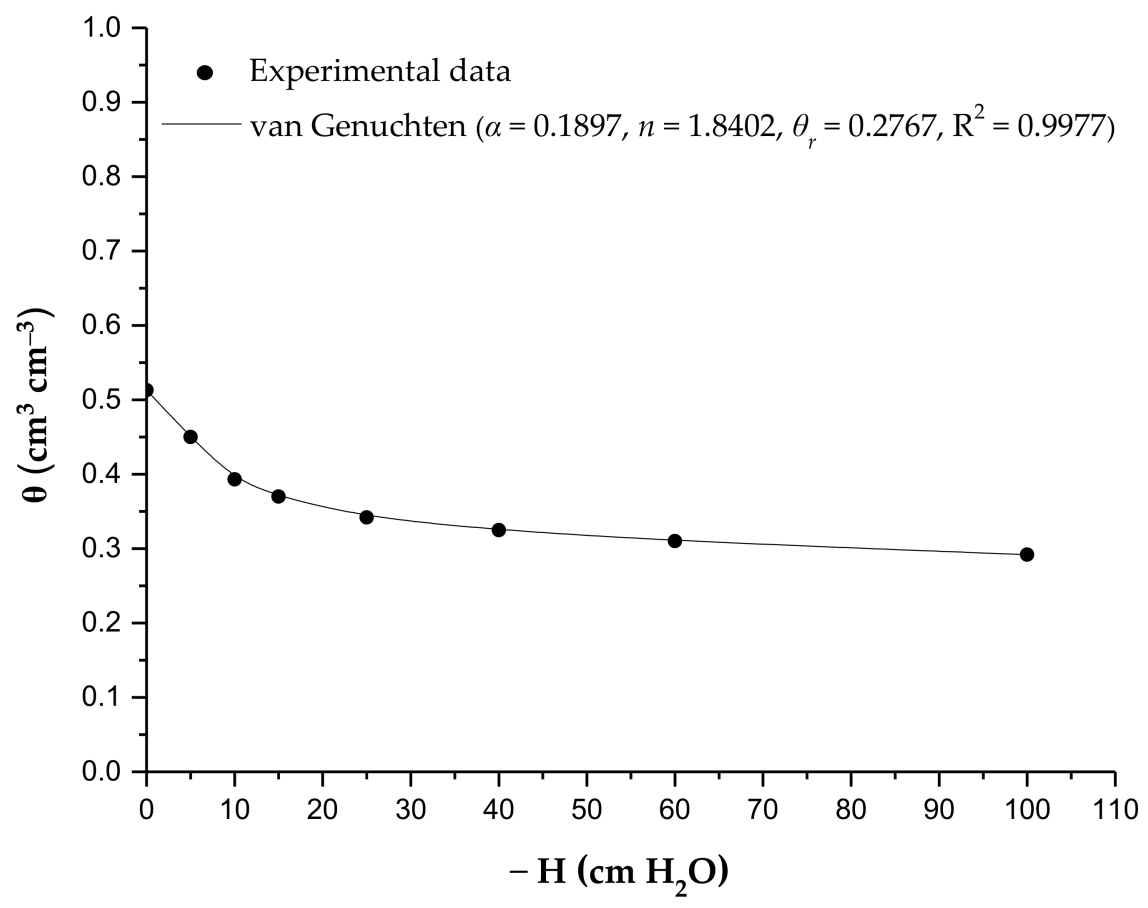

Figure 2. Experimental water retention data (symbol) and predicted curve (line) obtained by the Mualem-van Genuchten model using the RETC program for the substrate $S_{15}$ :Pum $70: C_{15}$ (subscripts show volumetric proportions of S:soil, Pum: pumice and C: grape marc compost). Values are the means of three replicates $(n=3)$.

The hydraulic characteristics derived from the water retention curve provide important information concerning plant growth and irrigation management. The main substrate hydraulic characteristics are presented in Table 2. Specifically, the total porosity (water content at $0 \mathrm{~cm}$ pressure head), the water content at -50 and $-100 \mathrm{~cm}$, as well as the easily available water (the amount of water released between -10 and $-50 \mathrm{~cm}$ ) and the air-filled porosity at $-50 \mathrm{~cm}$ are given. Also, the measured value of hydraulic conductivity at saturation is presented.

Table 2. Hydraulic characteristics of the substrate $S_{15}: P_{10}: C_{15}$ (subscripts show volumetric proportions of S:soil, Pum: pumice and C: grape marc compost).

\begin{tabular}{|c|c|c|c|c|c|}
\hline $\begin{array}{l}\text { Total Porosity } \\
\qquad\left(\mathrm{cm}^{3} \mathrm{~cm}^{-3}\right)\end{array}$ & $\begin{array}{l}\text { Water Content } \\
\text { at }-50 \mathrm{~cm} \\
\left(\mathrm{~cm}^{3} \mathrm{~cm}^{-3}\right)\end{array}$ & $\begin{array}{l}\text { Water Content } \\
\text { at }-100 \mathrm{~cm} \\
\left(\mathrm{~cm}^{3} \mathrm{~cm}^{-3}\right)\end{array}$ & $\begin{array}{c}\text { Easily } \\
\text { Available } \\
\text { Water }\left(\text { EAW) }{ }^{2}\right. \\
\left(\mathrm{cm}^{3} \mathrm{~cm}^{-3}\right)\end{array}$ & $\begin{array}{c}\text { Air-Filled Porosity } \\
\text { at }-50 \mathrm{~cm} \\
\left(\mathrm{~cm}^{3} \mathrm{~cm}^{-3}\right)\end{array}$ & $\begin{array}{c}\mathrm{Ks}^{3} \\
\left(\mathrm{~cm} \mathrm{~min} \mathrm{~min}^{-1}\right)\end{array}$ \\
\hline 0.513 & 0.3120 & 0.2920 & 0.081 & 0.201 & 0.547 \\
\hline
\end{tabular}

In the high irrigation treatment, with the aim of retaining the substrate water content in the easily available water range, when the FDR reading reached approximately $0.31 \mathrm{~cm}^{3} \mathrm{~cm}^{-3}$ (water content at $-50 \mathrm{~cm}$ ), plants were irrigated with the corresponding amount of water providing 100\% EAW, i.e., $8.1 \mathrm{~mm} \mathrm{H}_{2} \mathrm{O}$ or $1.95 \mathrm{~L} \mathrm{H}_{2} \mathrm{O}$. On the other hand, in the low irrigation treatment, with the aim of stressing plants, when the FDR reading reached approximately $0.29 \mathrm{~cm}^{3} \mathrm{~cm}^{-3}$ (water content at $-100 \mathrm{~cm}$ ), plants 
were irrigated with half of the amount of the high irrigation treatment, i.e., $4.05 \mathrm{~mm} \mathrm{H}_{2} \mathrm{O}$ or $0.975 \mathrm{~L}$ $\mathrm{H}_{2} \mathrm{O}$, raising the substrate water content to approximately $0.33 \mathrm{~cm}^{3} \mathrm{~cm}^{-3}$ (water content at $-30 \mathrm{~cm}$ ) and within the EAW range.

The unsaturated hydraulic conductivity values provide information of fundamental importance, because the rate of evapotranspiration is directly correlated to hydraulic conductivity, i.e., the water flow rate of the substrate has the ability to replace the water loss caused by evapotranspiration. In Figure 3, the measured value of hydraulic conductivity at saturation, as well as the predicted values of unsaturated hydraulic conductivity obtained by the Mualem-van Genuchten model within the range of water content between 0.513 and $0.292 \mathrm{~cm}^{3} \mathrm{~cm}^{-3}$ (at corresponding pressure heads between 0 and $-100 \mathrm{~cm}$, respectively) are presented. As shown, between two successive irrigations, a sharp decrease of the unsaturated hydraulic conductivity was observed within this range. Similar results have been reported by other reasearchers on growth substrates used for plant production [39,42]. Londra [39] found a decrease of five to six orders of magnitude in unsaturated hydraulic conductivity for peat and both mixtures of peat-perlite and coir-perlite, respectively, for a pressure heads range from 0 to $-70 \mathrm{~cm}$. Also, Da Silva et al. [42] reported a decrease of three orders of magnitude for peat for a range from 0 to $-25 \mathrm{~cm}$.

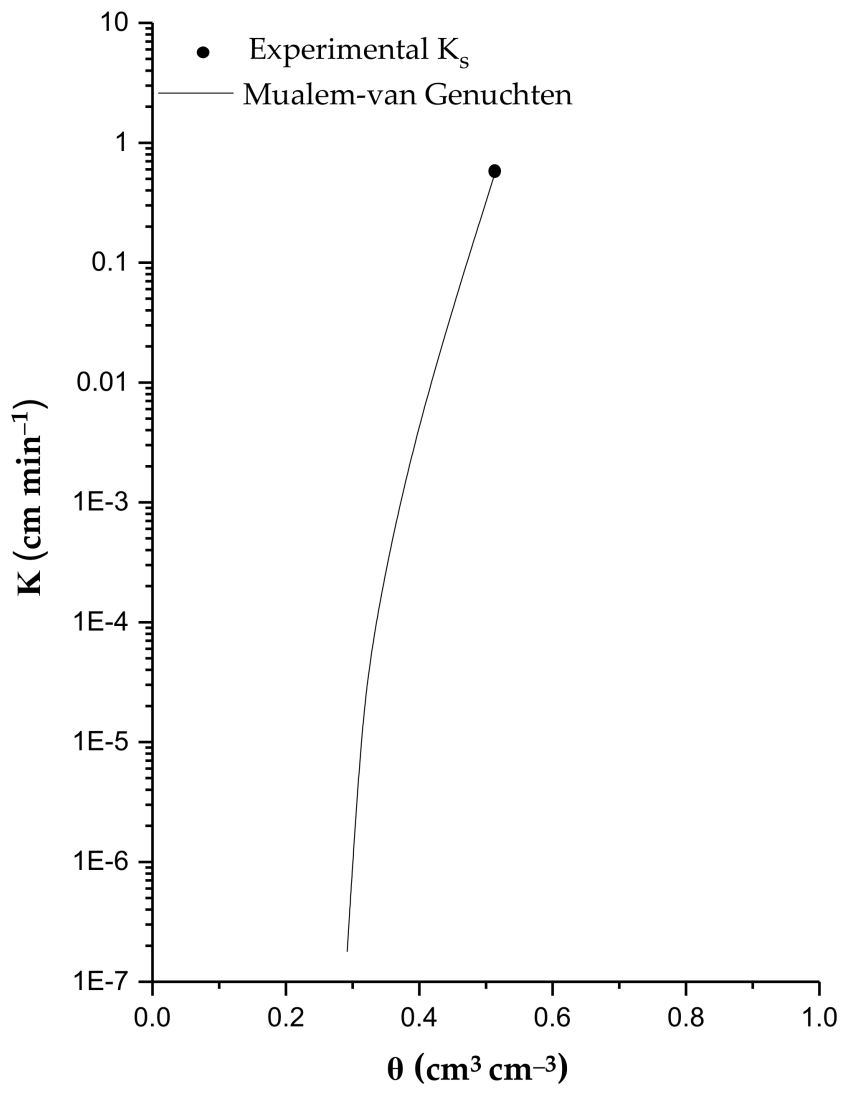

Figure 3. Experimental hydraulic conductivity at saturation (symbol) and predicted relationship between unsaturated hydraulic conductivity and water content (line) obtained by the Mualem-van Genuchten model using the RETC program for the substrate $S_{15}:$ Pum $_{70}: C_{15}$ (subscripts show volumetric proportions of S:soil, Pum: pumice and C: grape marc compost).

During plant growth in this study, the pressure heads varied from -10 to $-50 \mathrm{~cm}$ between two successive irrigations in the high irrigation treatment $(100 \%$ EAW) and from -30 to $-100 \mathrm{~cm}$ in the low irrigation treatment. In the case of the high irrigation treatment, hydraulic conductivity decreased by approximately two orders of magnitude (ranged from $4.06 \times 10^{-3}$ to $1.07 \times 10^{-5} \mathrm{~cm} \mathrm{~min}^{-1}$ ). On the other hand, in the case of the low irrigation treatment, hydraulic conductivity decreased by approximately 
two and a half orders of magnitude, ranging from $8.16 \times 10^{-5}$ to $1.78 \times 10^{-7}$ (Table 3 ). However, it is worth noting that the $\mathrm{K}$ values observed with the low irrigation treatment were much lower than those observed with the high irrigation treatment, confirming the presence of plant water stress.

Table 3. Measured values of water content $(\theta)$ and hydraulic conductivity $(K)$ at saturation $(H=0 \mathrm{~cm})$ and predicted ones obtained by the Mualem-van Genuchten model at water pressure heads $H=-10$, -30 , and $-50 \mathrm{~cm}$ for the substrate $S_{15}:$ Pum $_{70}: C_{15}$ (subscripts show volumetric proportions of S: soil, Pum: pumice and C: grape marc compost).

\begin{tabular}{|c|c|c|}
\hline $\begin{array}{c}H \\
(\mathrm{~cm})\end{array}$ & $\begin{array}{c}\theta \\
\left(\mathrm{cm}^{3} \mathrm{~cm}^{-3}\right)\end{array}$ & $\begin{array}{c}K \\
\left(\mathrm{~cm} \mathrm{~min} \min ^{-1}\right)\end{array}$ \\
\hline 0 & 0.513 & 0.547 \\
\hline-10 & 0.393 & $4.06 \times 10^{-3}$ \\
\hline-30 & 0.330 & $8.16 \times 10^{-5}$ \\
\hline-50 & 0.312 & $1.07 \times 10^{-5}$ \\
\hline-100 & 0.292 & $1.78 \times 10^{-7}$ \\
\hline
\end{tabular}

Nevertheless, it should be noted that in some cases, the predicted $K(\theta)$ values using the water retention curve data and the saturated hydraulic conductivity may deviate significantly from the actual $K(\theta)$ values [43-47].

\subsection{Symptoms Induced by Water Stress}

Schroll et al. [48] mention that it is possible for shrubs that are drought tolerant in their natural habitat to be unable to use their drought tolerance mechanisms properly in the shallow, nonnative soil of an extensive green roof system. The best indicator of the effect of drought is the visible symptoms of induced damage in plants (such as leaf chlorosis, browning, and necrosis) that affects the landscape visual quality $[49,50]$. With the exception of L. stoechas, all species appeared to be healthy and demonstrated no visual signs such as chlorosis or necrosis. L. stoechas started to demonstrate mild leaf rolling and chlorosis of the leaves in the low irrigated water treatment approximately two months after the start of the experiment (day 62), followed one month later by L. stoechas irrigated with the high water treatment (day 93) (data not shown). At the end of the experiment (day 123), only L. stoechas demonstrated moderate leaf rolling and chlorosis of the leaves in plants irrigated with the high water treatment and severe leaf rolling and chlorosis in plants irrigated with the low water treatment (Table 4). Concerning the control (high water treatment), leaf rolling is a drought response [48]. Plants watered with the low irrigation treatment showed more intense symptoms of chlorosis compared to the corresponding plants watered with the high irrigation treatment, suggesting that the smaller amount of irrigation contributed to increasing the intensity of leaf roll and chlorosis in the plant leaves. Similar research in an extensive green roof found that Cistus creticus spp. creticus under low irrigation demonstrated brown leaves that dropped and left the branch-ends bare, which was not aesthetically-pleasing and additionally created a fire hazard due to the presence of dried leaves [48]. The presence of water stress in the low irrigation treatment was determined (see Section 3.1). 
Table 4. Assessment of visual symptoms of lavender plants under different irrigation treatments at the end of the experiment (day 123), based on a 6-point scale (0-5). Differences between means shown with different letters (Tukey HSD, $p<0.05$ ).

\begin{tabular}{ccc}
\hline \multirow{2}{*}{ Species } & \multicolumn{2}{c}{ Irrigation Treatment } \\
& High & Low \\
\hline L. angustifolia & $5 \mathrm{a}$ & $5 \mathrm{a}$ \\
L. stoechas & $3 \mathrm{~b}$ & $2 \mathrm{c}$ \\
L. dentata var. candicans & $5 \mathrm{a}$ & $5 \mathrm{a}$ \\
L. dentata var. dentata & $5 \mathrm{a}$ & $5 \mathrm{a}$ \\
\hline
\end{tabular}

where 0: plant mortality, 1: very severe leaf rolling and chlorosis $>75 \%$, 2: severe leaf rolling and chlorosis $50-75 \%$ approximately, 3: moderate leaf rolling and chlorosis $25-50 \%$ approximately, 4 : mild leaf rolling and chlorosis $<25 \%$, 5: no leaf injury.

Furthermore, green roofs, and particularly extensive green roof systems, are characterized by the additive effect of both water deficits (water stress) and high air and substrate temperatures (heat stress) [51,52]. During warm periods, the relationship between air temperature and water in a substrate of an extensive green roof strongly influences plant growth. High substrate temperatures can limit root nutrient and water uptake and transport to leaves [53-56]. Also, the water in the substrate is susceptible to rapid evaporation [9]. In the current study, for all species and both irrigation treatments, the substrate cover from the vegetation within the surface area of each simulated extensive green roof system container was not complete (data not shown), and the meteorological data confirmed the presence of high air temperatures and moderate relative humidity (Figure 1). Further research considering substrate temperature (surface and inside) in relation to vegetation cover is necessary to study the effect of water stress on lavender species in more detail.

\subsection{Plant Growth}

Two-way ANOVA for data concerning the various plant growth biometrics measured throughout the duration of the experiment showed no significant interactions of the main experimental factors, i.e., among different lavender species and irrigation treatments. On the other hand, differences were shown within the experimental factors. Irrespective of lavender species, the percentage increase in height, shoot canopy diameter and growth index of plants watered with the low irrigation treatment showed smaller corresponding values than the plants watered with the high irrigation treatment $(p<0.05)$ (Table 5). Many wild plant species ceased growth due to adverse environmental conditions [57]. More specifically, during water stress, plants reduced their water requirements for the maintenance of high biomass by limiting their growth [58]. The greatest decrease in percentage increase was shown for the shoot canopy diameter. More specific, shoot canopy diameter percentage increase was reduced by $53 \%$ in plants watered with the low irrigation treatment, as opposed to plants watered with the high irrigation treatment (Table 5). Growth index percentage increase was reduced by $40 \%$ in plants watered with the low irrigation treatment, as opposed to plants watered with the high irrigation treatment. Finally, plant height percentage increase was reduced by $29 \%$ in plants watered with the low irrigation treatment, as opposed to plants watered with the high irrigation treatment. Despite the reduced percentage increase, all lavender species with the exception of L. stoechas, had a "healthy" appearance (i.e., without signs of leaf roll, chlorosis or necrosis). Therefore, the lavender species that showed satisfactory growth ( $L$. dentata var. candicans, $L$. dentata var. dentata and L. angustifolia) when watered with the low irrigation treatment should be considered in the design of extensive green roof systems to create aesthetically-pleasing green roofs for urban agriculture under conditions of water stress. Note that the water content of the substrate in the low irrigation treatment remained within the substrate's available water range (see 3.2. Symptoms Induced by Water Stress), and could contribute to conserving water resources without affecting the appearance of L. dentata var. candicans, L. dentata var. dentata and L. angustifolia. Further research is necessary to determine the effect of low irrigation 
defined by the substrate hydraulic properties of other ornamental plant species which could be grown on extensive green roofs.

Table 5. Interspecies differences and the effect of different irrigation amounts in the percentage increase in plant height $(\mathrm{H})$, shoot canopy diameter (D) and growth index (GI) ( $\mathrm{n}=12, p<0.05)$ of lavender species. Differences between means \pm S.E. shown in columns with different letters (Tukey HSD, $p<0.05)$.

\begin{tabular}{|c|c|c|c|c|}
\hline \multirow{2}{*}{ Species } & & \multicolumn{3}{|c|}{$\begin{array}{c}\text { Percentage Increase } \\
(\%)\end{array}$} \\
\hline & & $\mathbf{H}$ & D & GI \\
\hline L. dentata var. candicans & & $157 \pm 7.305 \mathrm{a}$ & $335 \pm 3.554 \mathrm{a}$ & $235 \pm 3.669 \mathrm{a}$ \\
\hline L. dentata var. dentata & & $79 \pm 7.305 b$ & $277 \pm 3.554 b$ & $173 \pm 3.669 \mathrm{~b}$ \\
\hline L. angustifolia & & $48 \pm 7.305 c$ & $178 \pm 3.554 c$ & $107 \pm 3.669 c$ \\
\hline L. stoechas & & $42 \pm 7.305 c$ & $53 \pm 3.554 \mathrm{~d}$ & $38 \pm 3.669 \mathrm{~d}$ \\
\hline \multicolumn{5}{|l|}{ Irrigation treatment } \\
\hline high & & $96 \pm 5.165 a$ & $237 \pm 2.513 a$ & $158 \pm 2.595 \mathrm{a}$ \\
\hline low & & $67 \pm 5.165 b$ & $184 \pm 2.513 b$ & $118 \pm 2.595 b$ \\
\hline \multicolumn{5}{|c|}{ Interaction (species $\times$ irrigation treatment) } \\
\hline \multirow{2}{*}{ L. dentata var. candicans } & $\times$ high & $179 \pm 10.331$ & $358 \pm 5.025$ & $256 \pm 5.189$ \\
\hline & $\times$ low & $135 \pm 10.331$ & $313 \pm 5.025$ & $214 \pm 5.189$ \\
\hline \multirow{2}{*}{ L. dentata var. dentata } & $\times$ high & $94 \pm 10.331$ & $299 \pm 5.025$ & $191 \pm 5.189$ \\
\hline & $\times$ low & $64 \pm 10.331$ & $254 \pm 5.025$ & $154 \pm 5.189$ \\
\hline \multirow{2}{*}{ L. angustifolia } & $\times$ high & $60 \pm 10.331$ & $213 \pm 5.025$ & $131 \pm 5.189$ \\
\hline & $\times$ low & $36 \pm 10.331$ & $143 \pm 5.025$ & $84 \pm 5.189$ \\
\hline \multirow{2}{*}{ L. stoechas } & $\times$ high & $51 \pm 10.331$ & $78 \pm 5.025$ & $56 \pm 5.189$ \\
\hline & $\times$ low & $32 \pm 10.331$ & $27 \pm 5.025$ & $21 \pm 5.189$ \\
\hline $\mathrm{F}_{\text {species }} / \mathrm{sig}$ & & * & * & * \\
\hline $\mathrm{F}_{\text {irrigation} / \mathrm{sig}}$ & & * & * & * \\
\hline $\mathrm{F}_{\text {interaction }} / \mathrm{sig}$. & & ns & ns & ns \\
\hline
\end{tabular}

ns: nonsignificant; ${ }^{*}$ denotes significant differences between means at $p<0.05$, shown with different letters within columns.

Differences in the percentage increase among lavender species are likely due to interspecies variations. Overall, among the different lavender species, L. dentata var. candicans showed the greatest increase in plant height, shoot canopy diameter and growth index, followed in descending order by L. dentata var. dentata, L. angustifolia and L. stoechas with the lowest value $(p<0.05)$ (Table 5). However, L. stoechas showed signs of stress even under the high irrigation treatment due to the additional stress induced under the extensive green roof system (see Section 3.2); therefore is not recommended that it be used in extensive green roofs. Interspecies differences in growth provide opportunities for combining the other three lavender species in various ways and creating aesthetically-pleasing planting schemes.

On day 123, the results obtained for the shoot dry weights were consistent with the results discussed above, due to interspecies differences $(p<0.05)$. Throughout the experiment, the shoot dry weights of $L$. dentata var. candicans showed the greatest value, followed in descending order by L. dentata var. dentata, L. angustifolia and L. stoechas with the lowest value $(p<0.05)$ (Table 6). 
Table 6. Interspecies differences and the effect of different irrigation amounts in the dry weight (DW) and stomatal conductance $\left(\mathrm{mmol} \mathrm{m}^{-2} \mathrm{~s}^{-1}\right)(\mathrm{n}=12, p<0.05)$ of lavender species. Differences between means \pm S.E. shown in columns with different letters (Tukey HSD, $p<0.05$ ).

\begin{tabular}{|c|c|c|c|}
\hline Species & & $\begin{array}{l}\text { Shoot Dry Weight } \\
\text { (g) }\end{array}$ & $\begin{array}{l}\text { Stomatal Conductance } \\
\quad\left(\mathrm{mmol} \mathrm{m} \mathrm{m}^{-2} \mathrm{~s}^{-1}\right)\end{array}$ \\
\hline L. dentata var. candicans & & $188 \pm 3.165 \mathrm{a}$ & $44 \pm 1.123 c$ \\
\hline L. dentata var. dentata & & $126 \pm 3.165 b$ & $47 \pm 1.123 b c$ \\
\hline L. angustifolia & & $76 \pm 3.165 c$ & $64 \pm 1.123 b$ \\
\hline L. stoechas & & $35 \pm 3.165 d$ & $50 \pm 1.123 \mathrm{a}$ \\
\hline \multicolumn{4}{|l|}{ Irrigation Treatment } \\
\hline high & & $120 \pm 2.238 \mathrm{a}$ & $54 \pm 0.794 \mathrm{a}$ \\
\hline low & & $92 \pm 2.238 b$ & $49 \pm 0.794 b$ \\
\hline \multicolumn{4}{|c|}{ Interaction (species $\times$ irrigation treatment) } \\
\hline \multirow[t]{2}{*}{ L. dentata var. candicans } & $\times$ high & $205 \pm 4.477$ & $49 \pm 1.589$ \\
\hline & $\times$ low & $171 \pm 4.477$ & $45 \pm 1.589$ \\
\hline \multirow[t]{2}{*}{ L. dentata var. dentata } & $\times$ high & $141 \pm 4.477$ & $45 \pm 1.589$ \\
\hline & $\times$ low & $111 \pm 4.477$ & $43 \pm 1.589$ \\
\hline \multirow[t]{2}{*}{ L. angustifolia } & $\times$ high & $86 \pm 4.477$ & $68 \pm 1.589$ \\
\hline & $\times$ low & $65 \pm 4.477$ & $60 \pm 1.589$ \\
\hline \multirow[t]{2}{*}{ L. stoechas } & $\times$ high & $49 \pm 4.477$ & $53 \pm 1.589$ \\
\hline & $\times$ low & $21 \pm 4.477$ & $48 \pm 1.589$ \\
\hline $\mathrm{F}_{\text {species }} / \mathrm{sig}$ & & $*$ & $*$ \\
\hline $\mathrm{F}_{\text {irrigation} / \text { sig. }}$ & & * & * \\
\hline $\mathrm{F}_{\text {interaction} / \text { sig. }}$ & & ns & ns \\
\hline
\end{tabular}

Drought avoidance physiological processes $[10,20]$ are expressed by species in various ways, such as stomatal regulation [10]. Stomatal conductance for both species and irrigation treatments on day 123 was significant $(p<0.05)$. Among lavender species, L. dentata var. candicans showed the least stomatal conductance; this was not significantly different from the stomatal conductance of L. dentata var. dentata, followed by L. stoechas and L. angustifolia, which had the largest stomatal conductance $(p<0.05)$ (Table 6). Additionally, all lavender species showed smaller stomatal conductance values under the low irrigation treatment $(p<0.05)$ (Table 6), suggesting that the plants were being subjected to stress. As mentioned, the presence of water stress was determined (see Section 3.2). However, the stomatal conductance values in all species watered with the high irrigation treatment $\cong 49-68 \mathrm{mmol}$ $\mathrm{m}^{-2} \mathrm{~s}^{-1}$ ) suggests that all species had undergone additional stress, possibly due to the additive effect of the adverse environmental conditions on the green roof (mainly by temperature) and potential root vulnerability to high substrate temperatures [18]. Substrate temperature in relation to air temperature was not studied in the present study; however, plants were exposed to high temperatures during the summer, i.e., ranging between $32.7-34.3^{\circ} \mathrm{C}$ (Figure 1), and therefore, in accordance with the findings of Vestrella et al. [19], substrate temperatures may have risen by $6{ }^{\circ} \mathrm{C}$, reaching $38.7-40.3^{\circ} \mathrm{C}$ or even higher if the absolute maximum daily temperatures were considered (often above $35^{\circ} \mathrm{C}$; see Figure 1 ).

Low stomatal conductance values in all lavender species also suggest the presence of a drought defense strategy. Our results agree with the findings of Sendo et al. [59] that on hot summer days, in an extensive green roof system with plants not being subjected to water stress, the drought-tolerant species Fragaria $\times$ ananassa, Thymus serphyllum, Evolvulus pilosus, Ophiopogon japonicus, Vinca major and Hedera helix had significantly lower stomatal conductance than the nondrought tolerant species Pelargonium $\times$ hortorum, Verbena $\times$ hybrida and Petunia $\times$ hybrida. In northeast Italy (Trieste), Salvia officinalis grown in $14 \mathrm{~cm}$ deep substrate of an extensive green roof system that received natural 
precipitation and irrigated only during prolonged drought periods showed a stomatal conductance value of $15.1 \mathrm{mmol} \mathrm{m}^{-2} \mathrm{~s}^{-1}$ and $83 \%$ desiccation of the shoots in August that recovered by $40 \%$ after autumn rains [60]. However, L. stoechas, with the least stomatal conductance $(p<0.05)$ (Table 6), had symptoms of chlorosis in the leaves. The effect of water stress on the growth of the lavender species is not straightforward due to the additive effect of air and substrate temperature mentioned above. Based on the findings of Huang et al. [53] that high substrate temperatures limit root uptake, and the findings of Theodosiou [56] that plant dimensions (height and shoot canopy diameter) can reduce substrate temperature through shading, it seems that the smaller percentage increase of L. stoechas in relation to the other species may have led to the occurrence of chlorosis in the leaves, i.e., L. stoechas created less shade on the substrate surface, causing greater substrate temperature and reduced nutrient uptake. Further research is necessary to determine the effect of irrigation in relation to both air and substrate temperature. However, potential carry-over effects from year to year due to water stress need to be studied in long-lived species, such as shrubs, as the induced stress may determine plant physiological and molecular changes [61].

Throughout the experiment, the biometrics (i.e., height, shoot canopy diameter and growth index) of plants watered with the high irrigation treatment showed greater values than plants watered with the low irrigation treatment $(p<0.05)$ (Figure 4). Similarly, in an extensive green roof, Cistus creticus spp. creticus showed reduced growth index when irrigated with low amount of water compared to nonwater stress irrigated plants [48]. With the exception of L. stoechas, despite the smaller biometric values, the other lavender species did not demonstrate visible symptoms of induced damage by water stress. Although the low irrigation treatment produced overall smaller plants, if necessary, it could contribute to conserving water resources without affecting the appearance of $L$. dentata var. candicans, L. dentata var. dentata and L. angustifolia. As mentioned, additional research to determine the effect of low irrigation defined by the substrate hydraulic properties on the growth of other ornamental plant species of extensive green roofs is recommended.
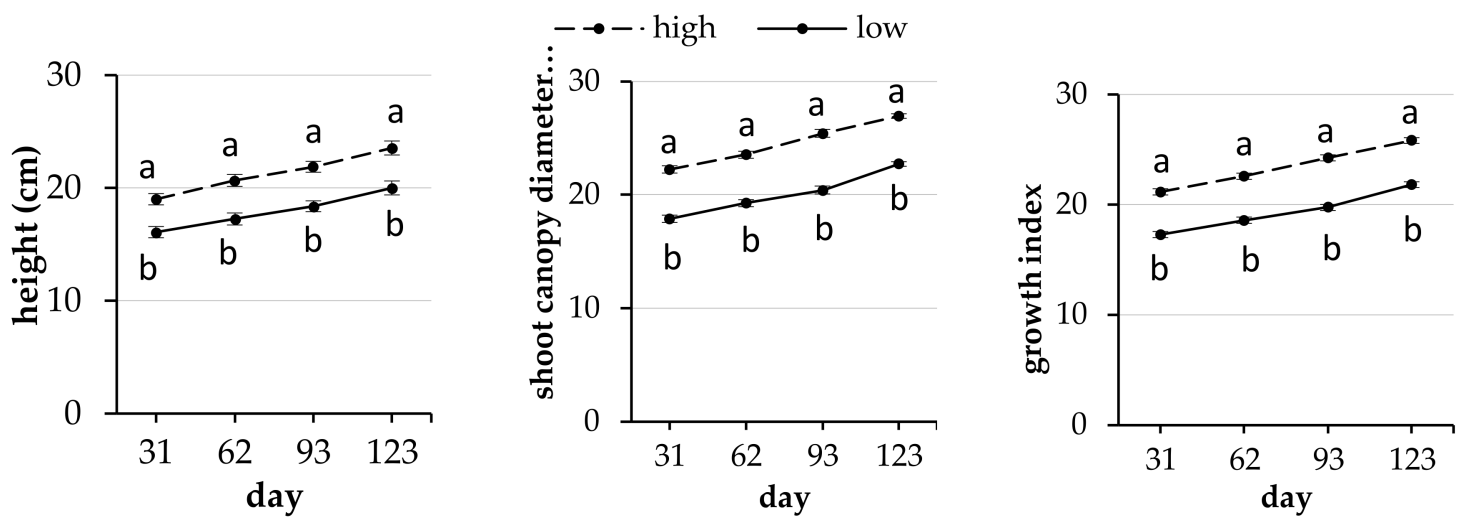

Figure 4. The effect of different irrigation amounts (high and low) on the biometrics (height, shoot canopy diameter and growth index) of Lavandula plants irrespective of species ( $\mathrm{n}=24, p<0.05)$. Differences between means \pm S.E. shown with different letters (Tukey HSD, $p<0.05$ ) for each individual biometric variable.

Significant differences $(p<0.05)$ were also shown among different lavender species in plant height, shoot canopy diameter and growth index. In the current study, the differences in plant height among the lavender species were likely due to interspecies variations. L. dentata var. candicans showed the greatest growth in height throughout the experiment, followed by L. dentata var. dentata $(p<0.05)$. The heights of both L. stoechas and L. angustifolia were similar but smaller than the corresponding heights of the other two lavender species $(p<0.05)$ (Figure 5). The differences in height among the lavender species that showed satisfactory growth (L. dentata var. candicans, L. dentata var. dentata and L. angustifolia) when watered with the low irrigation treatment should be considered in the design of 
extensive green roof systems to create aesthetically-pleasing green roofs for urban agriculture under conditions of water stress.

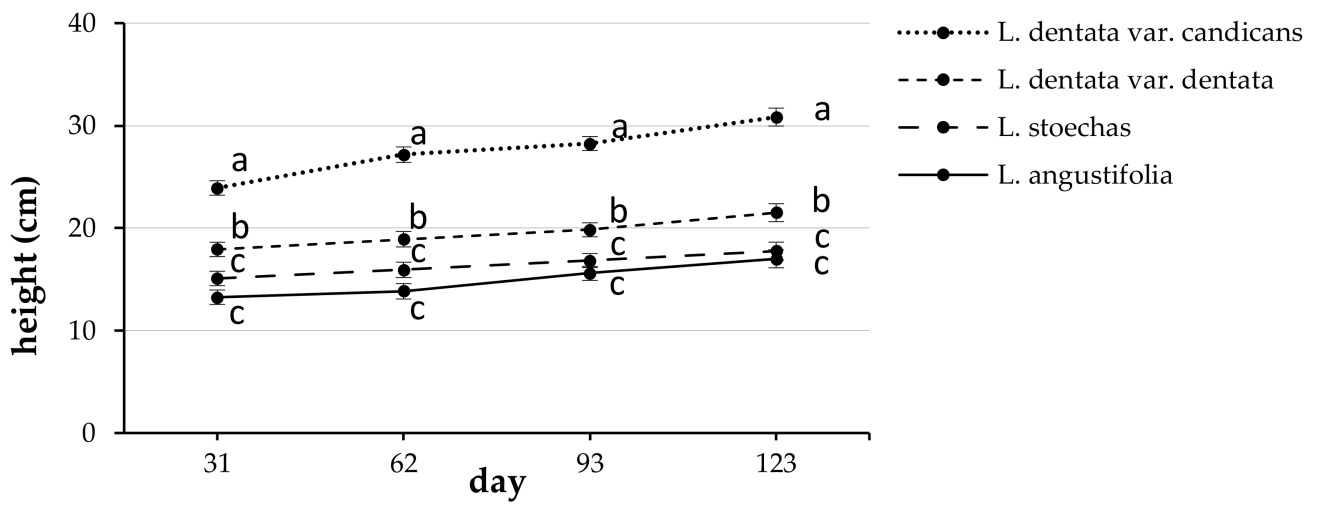

Figure 5. Lavandula interspecies differences in plant height $(\mathrm{n}=12, p<0.05)$. Differences between means \pm S.E. shown in columns with different letters (Tukey HSD, $p<0.05$ ).

With regards to shoot canopy diameter throughout the experiment, L. dentata var. candicans showed the greatest value, followed in descending order by L. dentata var. dentata, L. stoechas and L. angustifolia with the lowest value $(p<0.05)$ (Figure 6). These differences were due to interspecies variations. Shoot canopy diameter is an important determinant of plant success on green roofs, especially in extensive green roofs, as it influences vegetation cover [62]; vegetation cover shades the substrate surface, and hence, reduces substrate evaporation rates [18]. Therefore, the greater shoot canopy diameter of both $L$. dentata var. candicans and L. dentata var. dentata compared to the other lavender species suggests that they are more suitable for use in extensive green roof systems in comparison to the other lavender species studied. However, between the other two lavender species, only L. angustifolia showed satisfactory growth, possibly due to its dense foliage or drought tolerance mechanism [48]. As such, it is recommended for use in extensive green roof systems.

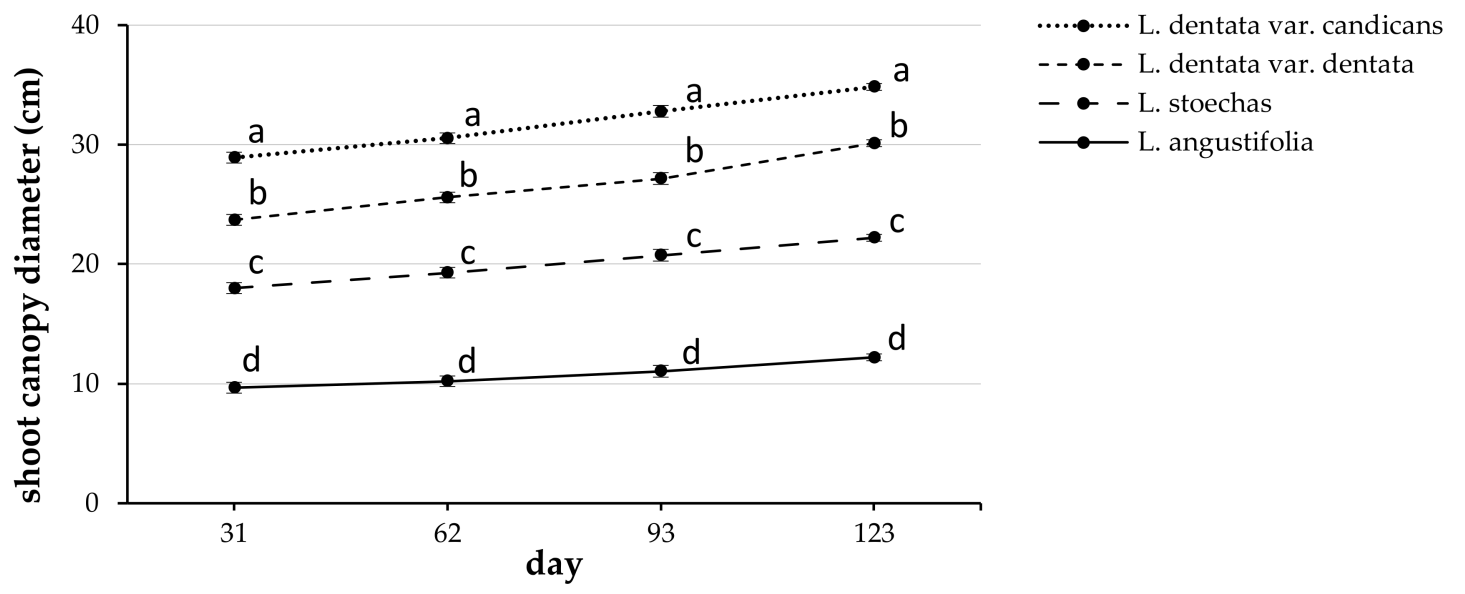

Figure 6. Lavandula interspecies differences in shoot canopy diameter $(\mathrm{n}=12, p<0.05)$. Differences between means \pm S.E. shown in columns with different letters (Tukey HSD, $p<0.05$ ).

Similarly, regarding the growth index throughout the experiment, $L$. dentata var. candicans showed the greatest value, followed in descending order by L. dentata var. dentata, L. stoechas and L. angustifolia with the lowest value $(p<0.05)$ (Figure 7). The growth index results were consistent with both the plant height and shoot canopy diameter results discussed above, and are due to interspecies differences $(p<0.05)$. 


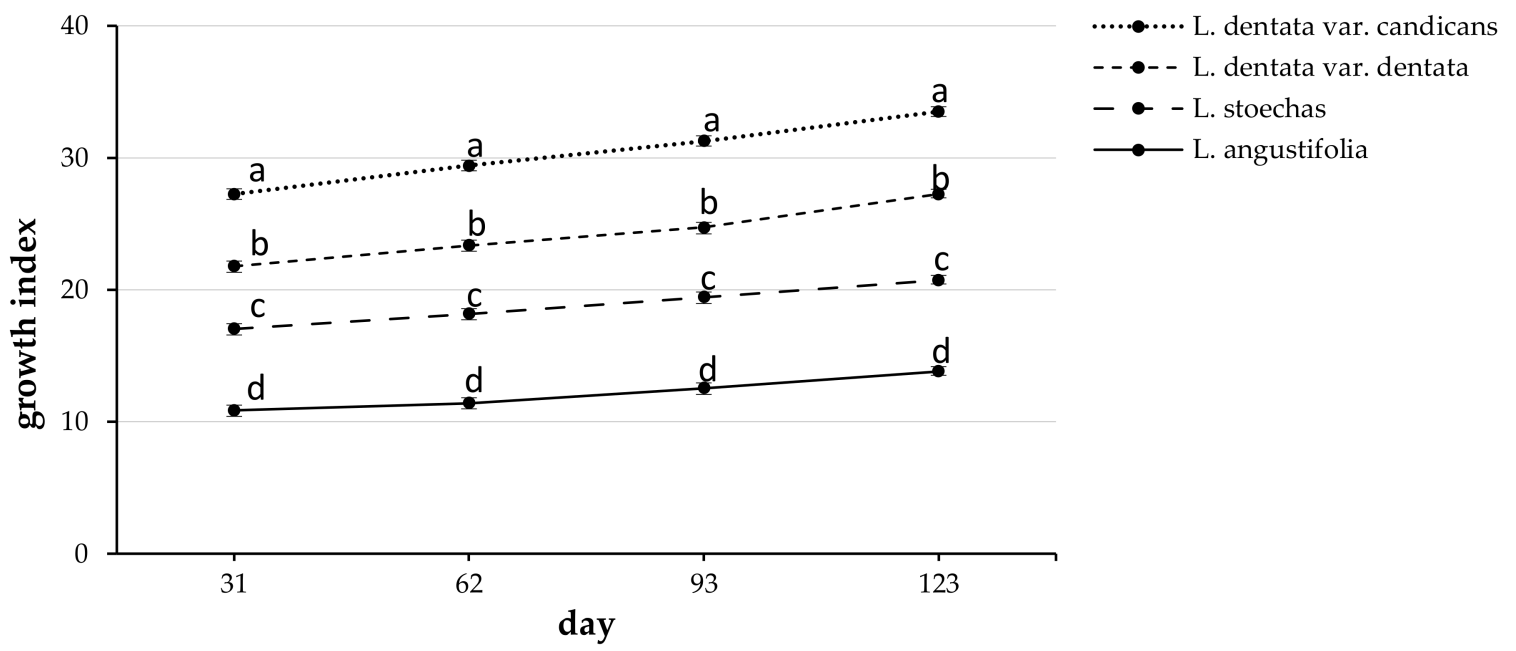

Figure 7. Lavandula interspecies differences in growth index $(\mathrm{n}=12, p<0.05)$. Differences between means \pm S.E. shown in columns with different letters (Tukey HSD, $p<0.05$ ).

\section{Conclusions}

The hydraulic properties (e.g. water retention curve, hydraulic conductivity) of substrates affect water availability and provide important information for irrigation management. In the current study, two amounts of water irrigation treatments (high and low) were applied within an available water range of an extensive green roof substrate based on its hydraulic properties. In general, plant growth was reduced in the low irrigation treatment. Among the various lavender species studied, L. dentata var candicans showed the greatest growth, while L. angustifolia showed the least. Overall, plant growth due to interspecies variation was as follows, in descending order: L. dentata var candicans, L. dentata var dentata, L. stoechas and L. angustifolia. All lavender species showed low stomatal conductance values, suggesting the presence of a drought defense strategy. L. dentata var. candicans showed the lowest stomatal conducatance value, similar to those of $L$. dentata var. dentata and followed in ascending order by L. stoechas and L. angustifolia, with the greatest stomatal conductance.

On the other hand, with the exception of L. stoechas, the appearance of all species studied was satisfactory. Therefore, the use of L. stoechas is not proposed, as the visual quality of the plant was reduced due to leaf roll and chlorosis induced by stress. Despite the reduced growth of lavender species watered with the low irrigation treatment, the satisfactory appearance (i.e., lack of damage induced symptoms) of the plants supports the use of L. dentata var candicans, L. dentata var dentata, and L. angustifolia under low irrigation. Further study on the effect of low irrigation within the substrate available water range determined by the substrate hydraulic properties on the growth of other ornamental plant species on extensive green roofs is recommended.

The differences in plant characteristics and size among $L$. dentata var candicans, $L$. dentata var dentata, and L. angustifolia can be considered in the design of extensive green roof systems including amphitheatrical planting schemes to create aesthetically-pleasing green roofs for urban agriculture. The larger L. dentata var candicans and L. dentata var dentata varieties are recommended for extensive green roofs, as they provide greater vegetation cover in substrates, potentially reducing the effect of high substrate temperatures due to shading. Further research is recommended to determine the effect of irrigation in relation to drought tolerance mechanisms, as well as both air and substrate temperatures in extensive green roof systems.

Author Contributions: Conceptualization, A.T.P.; methodology, A.T.P. and P.A.L.; formal analysis, A.T.P., P.T., P.A.L. and A.P.K.; investigation, P.T. and A.P.; writing-original draft preparation, A.P.; writing-review and editing, A.T.P., P.A.L. and A.P.K.; supervision, A.T.P. and P.A.L.; project administration, A.P. and P.T. All authors have read and agreed to the published version of the manuscript.

Acknowledgments: We would like to thank Kalantzis Plants for the free supply of lavender plants. 
Conflicts of Interest: The authors declare no conflict of interest.

\section{References}

1. Azunre, G.A.; Amponsah, O.; Peprah, C.; Takyi, S.A.; Braimah, I. A review of the role of urban agriculture in the sustainable city discourse. Cities 2019, 93, 104-119. [CrossRef]

2. Mougeot, L.J.A. Urban. Agriculture: Definition, Presence, Potentials and Risks, and Policy Challenges; Cities Feeding People Series Report 31; International Development Research Centre (IDRC): Ottawa, ON, Canada, 2000; 62p.

3. Marques-Perez, I.; del Rio, B.S.G. Identifying Functionality of Peri-Urban Agricultural Systems: A Case Study. In Urban Agriculture; Samer, M., Ed.; InTech: London, UK, 2016; pp. 61-88.

4. Artmann, M.; Sartison, K. The Role of Urban Agriculture as a Nature-Based Solution: A Review for Developing a Systemic Assessment Framework. Sustainability 2018, 10, 1-32. [CrossRef]

5. Dunnett, N.; Kingsbury, N. Planting Green Roofs and Living Walls; Timber Press: Portland, OR, USA, 2004; 254p.

6. Dubbeling, M.; Orsini, F.; Gianquinto, G. The Status and Challenges of Rooftop Agriculture. In Rooftop Urban Agriculture; Orsini, F., Dubbeling, M., de Zeeuw, H., Gianquinto, G., Eds.; Springer International Publishing: Cham, Switzerland, 2017; pp. 3-8.

7. Besir, A.B.; Cuce, E. Green roofs and facades: A comprehensive review. Renew. Sustain. Energy Rev. 2018, 82, 915-939. [CrossRef]

8. Paraskevopoulou, A.; Mitsios, I.; Fragkakis, I.; Nektarios, P.; Ntoulas, N.; Londra, P.; Papafotiou, M. The growth of Arthrocnemum macrostachyum and Halimione portulacoides in an extensive green roof system under two watering regimes. Agric. Agric. Proc. 2015, 4, 242-249. [CrossRef]

9. Savi, T.; Boldrin, D.; Marin, M.; Love, V.L.; Andri, S.; Trtiah, M.; Nardini, A. Does shallow substrate improve water status of plants growing on green roofs? Testing the paradox in two sub-Mediterranean shrubs. Ecol. Eng. 2015, 84, 292-300. [CrossRef]

10. Du, P.; Arndt, S.K.; Farrell, C. Is plant survival on green roofs related to their drought response, water use or climate or origin? Sci. Total Environ. 2019, 667, 25-32. [CrossRef]

11. Papafotiou, M.; Pergalioti, N.; Tassoula, L. Growth of Native Aromatic Xerophytes in an Extensive Mediterranean Green Roof as Affected by Substrate Type and Depth and Irrigation Frequency. HortScience 2013, 48, 1327-1333. [CrossRef]

12. Papafotiou, M.; Pergalioti, N.; Massas, I.; Kargas, G. Effect of Substrate Type and Depth and the Irrigation Frequency on Growth of Semiwoody Mediterranean Species in Green Roofs. Acta Hortic. 2013, 990, 481-486. [CrossRef]

13. Tassoula, L.; Papafotiou, M.; Liakopoulos, G.; Kargas, G. Growth of the Native Xerophyte Convolvulus cneorum L. on an Extensive Mediterranean Green Roof under Different Substrate Types and Irrigation Regimens. HortScience 2015, 50, 1118-1124. [CrossRef]

14. Papafotiou, M.; Tassoula, L.; Liakopoulos, G.; Kargas, G. Effect of substrate type and irrigation frequency on growth of Mediterranean xerophytes on green roofs. Acta Hortic. 2016, 1108, 309-315. [CrossRef]

15. Papafotiou, M.; Tassoula, L.; Kefalopoulou, R. Effect of substrate type and irrigation frequency on growth of Pallenis maritima on an urban extensive green roof at the semi-arid Mediterranean region. Acta Hortic. 2017, 1189, 275-278. [CrossRef]

16. Tassoula, L.; Papafotiou, M.; Fouskaki, M. Growth of the halophyte Atriplex halimus on a green roof at the semi-arid Mediterranean region as affected by substrate type and irrigation regime. Acta Hortic. 2017, 1189, 287-290. [CrossRef]

17. Baltzoi, P.; Fotia, K.; Kyrkas, D.; Nikolaou, K.; Paraskevopoulou, A.T.; Accogli, A.R.; Karras, G. Low water-demand plants for landscaping and agricultural cultivations-A review regarding local species of Epirus/Greece and Apulia/Italy. Agric. Agric. Proc. 2015, 4, 250-260. [CrossRef]

18. Wolf, D.; Lundholm, J.T. Water uptake in green roof microcosms: Effects of plant species and water availability. Ecol. Eng. 2008, 33, 179-186. [CrossRef]

19. Vestrella, A.; Biel, C.; Savè, A.; Bartoli, F. Mediterranean Green Roof Simulation in Caldes de Montbui (Barcelona): Thermal and Hydrological Performance Test of Frankenia laevis L., Dymondia margaretae Compton and Iris lutescens Lam. Appl. Sci. 2018, 8, 2497. [CrossRef] 
20. Bartlett, M.K.; Klein, T.; Jansen, S.; Choat, B.; Sack, L. The correlations and sequence of plant stomatal, hydraulic, and wilting responses to drought. PNAS 2016, 113, 13098-13103. [CrossRef] [PubMed]

21. Mansfield, T.J.; Atkinson, C.J. Stomatal behavior in water stressed plants. In Stress Responses in Plants: Adaptation and Acclimation Mechanisms; Alscher, R.G., Cumming, J.R., Eds.; Wiley-Liss: New York, NY, USA, 1990; pp. 241-264.

22. Arve, L.E.; Torre, S.; Olsen, J.E.; Tanino, K.K. Stomatal Responses to Drought Stress and Air Humidity. In Abiotic Stress in Plants-Mechanisms and Adaptations; Arun, K.S., Venkateswarlu, B., Eds.; Intech: Rijeka, Croatia, 2011; pp. 279-280.

23. Pirasteh-Anosheh, H.; Saed-Moucheshi, A.; Pakniyat, H.; Pessarakli, M. Stomatal responses to drought stress. In Water Stress and Crop. Plants: A Sustainable Approach, 1st ed.; Ahmad, P., Ed.; John Wiley \& Sons, Ltd.: Chichester, UK, 2016; Volume 1, pp. 24-40.

24. Torres-Ruiz, J.M.; Diaz-Espejo, A.; Morales-Sillero, A.; Martín- Palomo, M.J.; Mayr, S.; Beikircher, B.; Fernandez, J.E. Shoot hydraulic characteristics, plant water status and stomatal response in olive trees under different soil water conditions. Plant. Soil 2013, 373, 77-87. [CrossRef]

25. Casson, S.A.; Hetherington, A.M. Environmental regulation of stomatal development. Curr. Opinion Plant. Biol. 2010, 13, 90-95. [CrossRef]

26. De Boodt, M.; Verdonck, O. The physical properties of the substrates in horticulture. Acta Hortic. 1972, 26, 37-44. [CrossRef]

27. The Plant List, Version 1.1. 2013. Available online: http://www.theplantlist.org/1.1/browse/A/Lamiaceae/ Lavandula/\#statistics (accessed on 18 March 2020).

28. Upson, T. The taxonomy of the genus Lavandula, L. In Lavender The genus Lavandula; Lis-Balchin, M., Ed.; Taylor \& Francis: London, UK, 2002; pp. 2-34.

29. Lis-Balchin, M. General introduction to the genus Lavandula. In Lavender The genus Lavandula; Lis-Balchin, M., Ed.; Taylor \& Francis: London, UK, 2002; p. 1.

30. Haines, W.B. Studies in the physical properties of soils. V. The hysteresis effect in capillary properties and the modes of moisture distribution associated therewith. J. Agric. Sci. 1930, 20, 97-116. [CrossRef]

31. Van Genuchten, M.T.; Leij, F.J.; Yates, S.R. The RETC Code for Quantifying the Hydraulic Functions of Unsaturated Soils; U.S.D.A. (U.S. Department of Agriculture, Agricultural Research Service): Riverside, CA, USA, 1991.

32. Mualem, Y. A new model for predicting the hydraulic conductivity of unsaturated porous media. Water Resour. Res. 1976, 12, 513-522. [CrossRef]

33. Van Genuchten, M.T. A closed-form equation for predicting the hydraulic conductivity of unsaturated soils. Soil Sci. Soc. Am. J. 1980, 44, 892-898. [CrossRef]

34. Klute, A.; Dirksen, C. Methods of Soil Analysis, Part 1, Physical and Mineralogical Methods; Klute, A., Ed.; American Society of Agronomy: Madison, WI, USA, 1986; pp. 694-700.

35. IERSD-NOA. Monthly Bulletin; Institute of Environmental Research and Sustainable Development of the National Observatory of Athens: Penteli, Greece, 2016; Available online: https://meteo.gr/Monthly_Bulletins. cfm (accessed on 7 January 2020).

36. W.M.O. Guide to Meteorological Instruments and Methods of Observation; WMO-No. 8 (updated 2017); World Meteorological Organization (W.M.O.): Geneva, Switzerland, 2014; 1166p.

37. Raviv, M.; Lieth, J.H. Soilless Culture Theory and Practice; Elsevier BV: London, UK, 2008; p. 587.

38. Naaz, R.; Bussières, P. Particle Sizes Related to Physical Properties of Peat-Based Substrates. Acta Hortic. 2011, 893, 971-978. [CrossRef]

39. Londra, P.A. Simultaneous determination of water retention curve and unsaturated hydraulic conductivity of substrates using a steady-state laboratory method. HortScience 2010, 45, 1106-1112. [CrossRef]

40. Londra, P.A.; Paraskevopoulou, A.T.; Psychoyou, M. Evaluation of water-air balance of various substrates on begonia growth. HortScience 2012, 47, 1153-1158. [CrossRef]

41. Londra, P.A.; Psychoyou, M.; Valiantzas, J.D. Evaluation of substrate hydraulic properties amended by urea-formaldehyde resin foam. HortScience 2012, 47, 1375-1381. [CrossRef]

42. Da Silva, F.F.; Wallach, R.; Chen, Y. Hydraulic properties of Sphagnum peat moss and tuff (scoria) and their potential effects on water availability. Plant. Soil 1993, 154, 119-126. [CrossRef]

43. Talsma, T. Prediction of hydraulic conductivity from soil water retention data. Soil Sci. 1985, 140, $184-188$. [CrossRef] 
44. Poulovassilis, A.; Polychronides, M.; Kerkides, P. Evaluation of various computational schemes in calculating unsaturated hydraulic conductivity. Agric. Water Manag. 1988, 13, 317-327. [CrossRef]

45. Valiantzas, J.D.; Sassalou, A. Laboratory determination of unsaturated hydraulic conductivity using a generalized-form hydraulic model. J. Hydrol. 1991, 128, 293-304. [CrossRef]

46. Kargas, G.; Londra, P.A. Effect of tillage practices on the hydraulic properties of a loamy soil. Desalin. Water Treat. 2015, 54, 2138-2146. [CrossRef]

47. Londra, P.; Kargas, G. Evaluation of hydrodynamic characteristics of porous media from one-step outflow experiments using RETC code. J. Hydroinform. 2018, 20, 699-707. [CrossRef]

48. Schroll, E.; Lambrinos, J.G.; Sandrock, D. An Evaluation of Plant Selections and Irrigation Requirements for Extensive Green Roofs in the Pacific Northwestern United States. HortTechnology 2011, 21, 314-322. [CrossRef]

49. Vahdati, N.; Tehranifar, A.; Kazemi, F. Assessing chilling and drought tolerance of different plant genea on extensive green roofs in an arid climate region in Iran. J. Environ. Manage. 2017, 192, 215-223. [CrossRef] [PubMed]

50. Nazemi Rafi, Z.; Kazemi, F.; Tehranifar, A. Effects of various irrigation regimes on water use efficiency and visual quality of some ornamental herbaceous plants in the field. Agr. Water Manage. 2019, 212, 78-87. [CrossRef]

51. Savi, T.; Dal Borgo, A.; Love, V.L.; Andri, S.; Tretiach, M.; Nardini, A. Drought versus heat: What's the major constraint on Mediterranean green roof plants? Sci. Total Environ. 2016, 566-567, 753-760. [CrossRef]

52. Kazemi, F.; Mohorko, R. Review on the roles and effects of growing media on plant performance in green roofs in world climates. Urban. Forestry and Urban. Greening 2017, 23, 13-26. [CrossRef]

53. Huang, B.; Rachmilevitch, S.; Xu, J. Root carbon and protein metabolism associated with heat tolerance. J. Experimental Botany 2012, 63, 3455-3465. [CrossRef]

54. Olivieri, F.; Di Perna, C.; D'Orazio, M.; Olivieri, L.; Neila, J. Experimental measurements and numerical model for the summer performance assessment of extensive green roofs in a Mediterranean coastal climate. Energ. Buildings 2013, 63, 1-14. [CrossRef]

55. Simmons, M.T.; Gardiner, B.; Windhager, S.; Tinsley, J. Green roofs are not created equal: The hydrologic and thermal performance of six different extensive green roofs and reflective and non-reflective roofs in a sub-tropical climate. Urban. Ecosyst. 2008, 11, 339-348. [CrossRef]

56. Theodosiou, T.G. Summer period analysis of the performance of a planted roof as a passive cooling technique. Energ. Buildings 2003, 35, 909-917. [CrossRef]

57. Chapin, F.S., III. The mineral nutrition of wild plants. Ann. Rev. Ecol. Syst. 1983, 11, 233-260. [CrossRef]

58. Schuppler, U.; He, P.H.; John, P.C.L.; Munns, R. Effects of water stress on cell division and cell-division-cycle2-like cell-cycle kinase activity in wheat leaves. Plant. Physiol. 1998, 117, 667-678. [CrossRef] [PubMed]

59. Sendo, T.; Kanechi, M.; Uno, Y.; Inagaki, N. Evaluation of Growth and Green Coverage of Ten Ornamental Species for Planting as Urban Rooftop Greening. J. Japan. Soc. Hort. Sci. 2010, 79, 69-76. [CrossRef]

60. Savi, T.; Andri, S.; Nardini, A. Impact of different green roof layering on plant water status and drought survival. Ecol. Eng. 2013, 57, 188-196. [CrossRef]

61. Mirás-Avalos, J.M.; Pérez-Sarmiento, F.; Alcobendas, R.; Alarcón, J.J.; Mounzer, O.; Nicolás, E. Using midday stem water potential for scheduling deficit irrigation in mid-late maturing peach trees under Mediterranean conditions. Irr. Sci. 2016, 32, 161-173. [CrossRef]

62. Molineux, C.J.; Fentiman, C.H.; Gange, A.C. Characterising alternative recycled waste materials for use as green roof growing media in the U.K. Ecol. Eng. 2009, 35, 1507-1513. [CrossRef]

(C) 2020 by the authors. Licensee MDPI, Basel, Switzerland. This article is an open access article distributed under the terms and conditions of the Creative Commons Attribution (CC BY) license (http://creativecommons.org/licenses/by/4.0/). 